C. Frantz
D. Annane

Hydrokortison im septischen Schock, bei ARDS und schwerer Pneumonie

Received: 14 February 2006

Accepted: 9 March 2006

Pr. Dr. med. Djillali Annane (

Service de Réanimation Médicale et Chiurgicale

Hôpital Raymond Poincaré

104, boulevard Raymond Poincaré

92380 Garches, France

Tel.: +33-147 107778

Fax: +33-147107783

E-Mail: djillali.annane@rpc.ap-hop-paris.fr

Christian Frantz

Innere Medizin V

Universitätskliniken des Saarlandes

Homburg, Germany

\title{
Hydrocortisone in septic shock, ARDS and severe pneumonia
}

Zusammenfassung Hydrokortison konnte die Mortalität und die Dauer des septischen Schocks senken. Neuere Untersuchungen weisen auf einen Benefit der sogenannten Substitutionstherapie bei schwerer Pneumonie und Sepsis hin, während beim ARDS die Studien geteilte Resultate aufweisen. Der Mechanismus für die durch Hydrokortison bedingten Verbesserungen ist nicht erklärt, aber eine bessere VasopressorenAntwort und die Beeinflussung einer überschießenden Immunreaktion scheinen von Bedeutung zu sein. Die Patienten mit Nebenniereninsuffizienz scheinen desweiteren am meisten von einer solchen Hydrokortisontherapie zu profitieren. Das Screening einer solchen Dysfunktion sollte bei jedem Intensivpatienten mit schwerer Erkrankung erfolgen.

Schlüsselwörter ARDS Sepsis - septischer Schock -
Hydrokortison - Pneumonie Nebenniereninsuffizienz

Summary Hydrocortisone has decreased shock duration and improved outcome in patients with septic shock. More recent trials have suggested a positive effect of this so-called replacement therapy in severe pneumonia and sepsis. The results of hydrocortisone during ARDS are equivocal. The mechanism responsible for the hydrocortisone-induced benefit remains uncertain, but improved vasopressor response and the restrain of exaggerated systemic inflammation may be important. Adrenal insufficient screening should be performed in every ICU patient with severe disease.

Key words ARDS - sepsis septic-shock - Hydrocortisone Pneumonia - adrenal insufficiency

\section{Introduction}

Ever since the discovery of the hypothalamic-pituitary-adrenal axis and the consequences of its dysfunction by Thomas Addison in 1855, the corticoid replacement therapy has remained controversial [1]. This is especially true for its use in the ICU where corticosteroids were used in ARDS, sepsis and septic shock. During the 1980's high dose corticosteroid therapy (6-8 g/d) for a short time (4-24 h) was used to treat those life-threatening conditions with the aim of suppressing an exacerbated inflammatory response $[2,3]$. However soon its efficacy was questioned as several clinical studies demonstrated no benefit so that the strategy was dismissed [4]. In the late 1990's as well as at the beginning of the new millennium, a more profound understanding of the pathophysiology of adrenal insufficiency led to a revival of the replacement strategy. 


\section{The adrenal gland and glucocorticoids}

The human adrenal gland, weighing about $4-6 \mathrm{~g}$, is subdivided into two functional units: the medulla and the cortex. The adrenal cortex is partitioned into three concentric zones of steroid-synthesizing cells: the glomerulosa producing the mineralocorticoids (aldosterone), the reticularis secreting the androgens (dihydroepiandrosterone, $\Delta 4$-androstenedione) while the production of the glucocorticoids (cortisol) lies in the fasciculata. The adrenal medulla produces sympathetic hormones such as epinephrine or norepinephrine.

The basic compound necessary for the production of steroids is cholesterol. Cholesterol is captured from the low density lipoproteins (LDL) and transformed by numerous enzymes such as cytochromes and $3 \beta$-hydrosteroid dehydrogenase.

Cortisol is transported in the blood in three forms: free cortisol, cortisol bound to the proteins as well as cortisol metabolites. Free cortisol, which is only found in small quantities in the plasma (5$10 \%)$, represents the active form. The two main binding proteins are the cortisol-binding protein (CBG) and albumin. Cortisol is metabolized in the liver where it is inactivated by $11 \beta$-hydroxysteroid dehydrogenase. The half-life of cortisol is 60-70 min, while it is $180 \mathrm{~min}$ for hydrocortisone and methylprednisolone.

The secretion of cortisol is tightly regulated by two major glands: the hypothalamus exerts its action on the pituitary gland by secreting cortisol releasing hormone $(\mathrm{CRH})$ while the pituitary gland itself stimulates the adrenal gland by releasing adrenocorticotropic hormone (ACTH) (Fig. 1). The cortisol plasma concentration follows a diurnal rhythm with its peak concentration between 7 and 8 am each day and a nadir about midnight. This diurnal cycle is lost in case of an aggression like an infection.

\section{Molecular actions and consequences on the inflammatory response of glucocorticoids}

Because of its lipophylic nature, cortisol enters the cell passively through its membrane. It then binds to the glucocorticoid receptor $a(\mathrm{GR} a)$ which, in the absence of cortisol, forms an inactive heterodimer with several heat-shock proteins (HSP). In the presence of cortisol, GR $a$ is dissociated from the HSP so that it is able to enter the cellular nucleus through the nuclear pores. As a dimer, it binds then to the glucocorticoid receptor elements (GRE) and modulates the transcription of numerous genes, inducing the production or suppression of numerous proteins

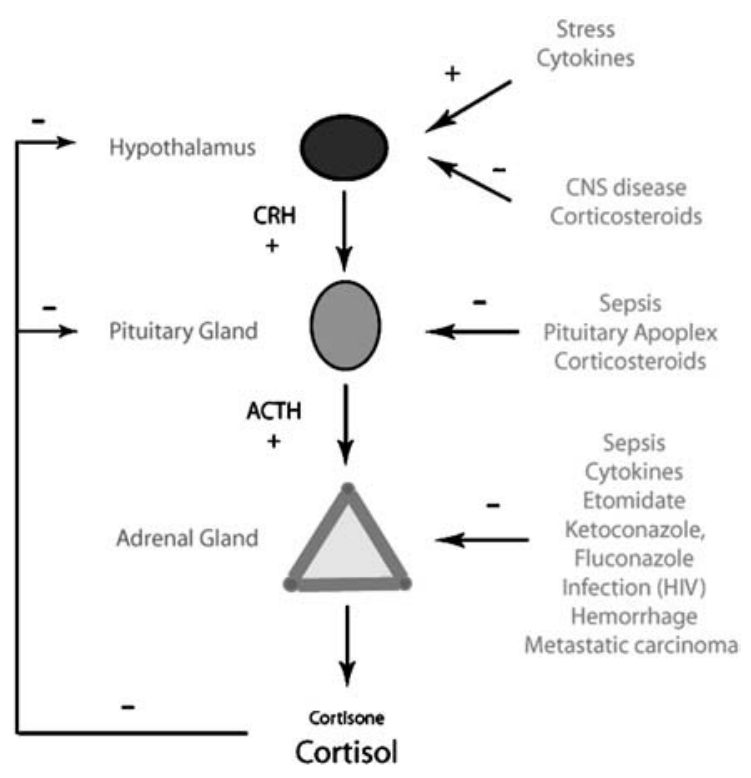

Fig. 1 The hypothalamic-pituitary-adrenal axis and its aggressors (CRH corticotropin-releasing hormone, $A C T H$ adrenocorticotropic hormone)

involved in the inflammatory process. Most importantly, glucocorticoids exert their anti-inflammatory action by suppressing the production of the pro-inflammatory cytokine NF- $\kappa \mathrm{B}$. This suppresses the production of almost all pro-inflammatory cytokines such as tumor necrosis factor $\alpha$ (TNF- $\alpha$ ), interferon$\gamma($ IFN- $\gamma)$ and several interleukins (IL-1, IL-2, IL-3 IL-6, IL-12) (Fig. 2).

As a result, glucocorticoids block the apoptosis of neutrophils while promoting cell death from eosinophils and basophils. Furthermore, glucocorticoids enhance the clearance of foreign antigens and inhibit their presentation by blocking the maturation of dendritic cells. By blocking the production of IL-12, glucocorticoids slow the development of the Th1-directed cellular immune response while promoting the Th2-directed humoral response by enhancing the IL-10 secretion. In short, glucocorticoids restrain systemic inflammation preventing an overreaction of the immune system to foreign antigens. Unfortunately by doing so, they also increase the probability of opportunistic infections $[5,6]$.

\section{Origin of the adrenal insufficiency}

Pituitary insufficiency is a common condition in the critically ill. Of all patients admitted to the ICU, $30 \%$ have an altered hypothalamic-pituitary-adrenal axis, in the septic shock group the incidence even exceeds $60 \%$ [7-9]. There are multiple reasons for this insufficiency (Table 1). 
Fig. 2 The glucocorticoid signaling pathway (GRaa Glucocorticoid receptor $a$, GRE glucocorticoid responsive element, HSPS heat shock proteins

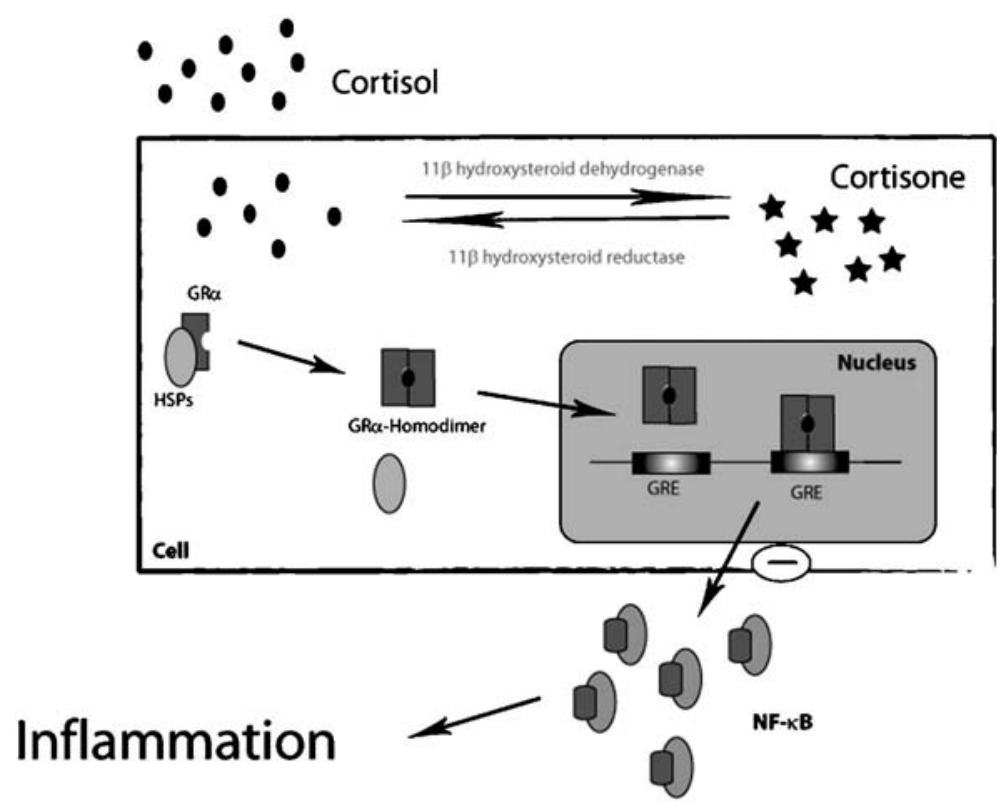

Table 1 Origin of the adrenal insufficiency

\begin{tabular}{ll}
\hline Primary adrenal & Tuberculosis \\
insufficiency & Systemic fungal infection \\
& Auto-immune adrenalitis \\
& HIV infection \\
& Antiphospholipid syndrome \\
& Metastatic carcinoma (Lungs +++) \\
& Acute hemorrhage (Meningococcemia, Disseminated \\
intravascular coagulation) & Head trauma \\
Secondary adrenal & Pituitary or metastatic tumor \\
insufficiency & Pituitary surgery or radiation \\
& Glucocorticoid treatment (systemic or topical) \\
Drugs inducing & Anticoagulants \\
adrenal insufficiency & Aminoglutethimide \\
& Mitotane \\
& Ketoconazole \\
& Fluconazole \\
& Etomidate \\
& Dexmedetomidine \\
& Phenobarbital \\
& Phenytoin \\
& Rifampicine \\
& Medroxyprogesterone \\
& Anti-depressant drugs \\
& Opiate drugs \\
\end{tabular}

The adrenal gland itself may be destroyed resulting in a primary adrenal insufficiency. Tuberculosis was the leading cause of acute and chronic adrenal insufficiency until the discovery of modern antibiotics. Later in the 1980's, the emergence of immunosuppression and immunosuppressive diseases as found, i.e., in HIV, AIDS or transplanted patients, became the most frequent cause of primary adrenal insufficiency. Indeed, human cytomegalovirus has been found in the adrenal gland in $88 \%$ of patients who died of AIDS. Cyryptococcus neoformans, Toxoplasma gondii, Histoplasma capsulatum infection are also responsible of the destruction of the suprarenal glandular tissue [10]. Numerous drugs used in the immunosuppressed patient impair adrenal function (notably ketoconazole, fluconazole or rifampin) [11-13]. Other drugs commonly used in the ICU are responsible for either a transitory or prolonged adrenal insufficiency. Most importantly, etomidate impacts steroidogenesis by blocking the adrenal mitochondrial hydroxylase resulting in a primary adrenal insufficiency. As a consequence, the use of this imidazole as an induction agent should possibly be avoided in patients with a septic condition $[14,15]$. Another cause of primary adrenal insufficiency is an acute hemorrhage of the adrenal tissue as found in disseminated intravascular coagulation, meningococcemia, or anticoagulation.

On the other hand, the destruction of the pituitary gland or the hypothalamus leads to secondary adrenal insufficiency. The most common condition responsible for this is sepsis and SIRS. The mechanisms are not fully understood yet, but it appears that numerous circulating pro-inflammatory factors such as TNF- $a$ or neutrophil-derived corticostatins inhibit the ACTH release of the pituitary gland [16].

Glucocorticoids such as prednisolone, methylprednisolone or dexamethasone may also induce secondary adrenal insufficiency by suppressing ACTH production. The degree of suppression depends largely on the time of steroid administration, but there is a 
nonpredictable individual susceptibility as well [17]. Glucocorticoids do not affect the HPA axis when taken for less than 5 days. A treatment duration of 5-30 days induces an adrenal insufficiency which is reversible within 14 days. When glucocorticoids are taken for more than 30 consecutive days, the HPA recovery may last as long as 1 year $[18,19]$ It is important to note that even inhaled glucocorticoids as used in asthmatics or in COPD patients may induce a HPA insufficiency to a varying degree $[20,21]$.

A peripheral glucocorticoid resistance may also be responsible for a relative adrenal insufficiency. In critical illness, glucocorticoid delivery can be decreased by a low serum glucocorticoid binding globulin $(\mathrm{CBG})$ concentration and activity $[22,23]$. The cleavage of $\mathrm{CBG}$ at the inflammatory site might be altered by a reduced neutrophil elastase. Furthermore, an increased activity of the 11- $\beta$ hydroxysteroid dehydrogenase (HSD) induced by several cytokines (Il-2, Il-4, Il-12) enhances the conversion of the active cortisol to the inactive cortisone. As a consequence the cortisol concentration at the inflammatory site is reduced resulting in a relative adrenal insufficiency with significantly increased serum cortisol levels ( $\geq 34 \mathrm{~g} / \mathrm{dl})$.

\section{Diagnosis of adrenal insufficiency}

The diagnosis of an HPA failure is based on the serum cortisol level. As the critical ill patient looses his diurnal variation of the cortisol secretion, a specific timing for the cortisol blood level is not necessary and can be done at any time during the day [24]. The minimal level which is considered sufficient for a major stress has been much discussed as the proposed cortisol level ranges from 10 to $34 \mu \mathrm{g} /$ dl. Several studies have established a threshold level of $19 \mu \mathrm{g} / \mathrm{dl}$ as indicator for adrenal insufficiency [25-27]. When serum cortisol levels peaks above $19 \mu \mathrm{g} / \mathrm{dl}$, an adrenal stimulation test should be done. An increment $(\Delta \max )$ of less than $9 \mu \mathrm{g} / \mathrm{dl}$ indicates adrenal insufficiency while a plasma cortisol level over $34 \mu \mathrm{g} / \mathrm{dl}$ suggests a tissue resistance to glucocorticoids (Fig. 3) [27].

The gold standard for adrenal stimulation remains the insulin-induced hypoglycemia test. Most experts agree that due to the contraindication of this test in critically ill patients, the "short synacthen stimulation test" with $250 \mu \mathrm{g}$ of ACTH (SST) is the most useful diagnostic tool [27, 28]. The low dose short synacthen stimulation test with $1 \mu \mathrm{g}$ of ACTH

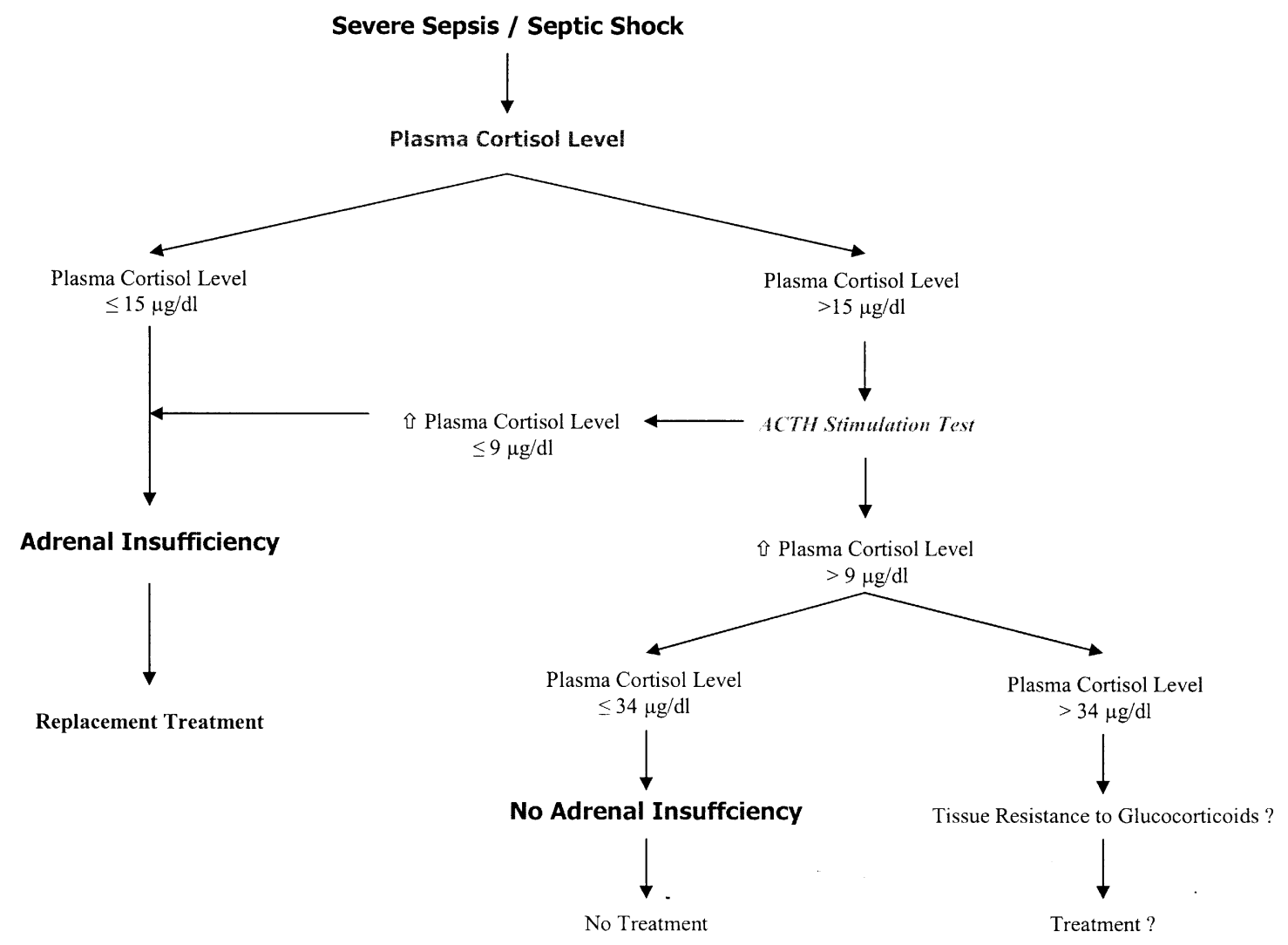

Fig. 3 Detection and treatment strategy during sepis and septic shock 
(LDSST) may have better sensitivity. However, in the absence of major supportive trials, validation is still required.

It is important to note that the sensitivity and specificity of the ACTH stimulation tests is not good enough to detect all HPA failures by the scheme described above. Another issue which needs to be considered is the bypassing of the CNS-hypothalamo-pituitary axis which is not assessed by the SST or LDSST. An additional corticotropin releasing hormone (CRH) test was proposed by some authors. This has not yet been evaluated in critically ill patients and should not be used in current practice [29]. Hence clinical judgment remains one of the most important issues for deciding which patient needs replacement therapy [30].

\section{Outcome of adrenal insufficiency}

Based on the criteria above, the outcome of patients in septic shock has been evaluated. Indeed, basal cortisol levels as well as the cortisol response to stimulation by $250 \mu \mathrm{g}$ synthetic ACTH (short synacthen test or SST) have been established as independent predictors of 28-day mortality. The classification into one of three groups based on cortisol levels has been proposed. The group with the worst outcome had a basal cortisol level $<34 \mu \mathrm{g} / \mathrm{dl}$ and were non-responders to the SST (28-day mortality $=82 \%)$. Basal cortisol levels $>34 \mu \mathrm{g} / \mathrm{dl}$ and a response $>9 \mu \mathrm{g} / \mathrm{dl}$ to the SST was linked to the best outcome (28-day mortality $=26 \%)$ [31]. Based on those findings, numerous clinical trials have been set up to determine the efficiency of an adrenal substitution therapy in critical illness.

\section{Treatment with low dose glucocorticoids in septic shock}

Based on the results of the study above, Annane et al. assessed low dose glucocorticoid replacement therapy in septic shock in a randomized, doubleblind, placebo-controlled trial including 300 patients. Hydrocortisone was given intravenously on a daily basis every $6 \mathrm{~h}$ as a $50 \mathrm{mg}$ bolus. Moreover, a concomitant mineralocorticoid replacement therapy with a daily oral dose of $50 \mu \mathrm{g}$ of $9 a$-fludrocortisone was administered. The treatment was introduced at the beginning of the septic shock and continued for 7 days. Eligible patients underwent a SST at the beginning of the replacement strategy subdividing the study population into responders $(23 \%)$ and non-responders $(77 \%)$ to the SST.
In the non-responder group, the 28-day mortality was reduced significantly: 73 deaths $(62 \%)$ were documented in the placebo-group, while there were 60 deaths $(53 \%)$ in the hydrocortisone group. The duration of shock was reduced and vasopressors were withdrawn within 28 days in $40 \%$ of the placebo group and in $57 \%$ in the treatment group.

These results were not found in the responder group, where mortality and shock duration were similar in the treated and the placebo group. Hence there is no benefit of hydrocortisone treatment in patients with an intact HPA axis [32]. It is important to note that there were no significant differences in adverse effects between the two groups. Indeed, low dose hydrocortisone treatment did not induce superinfections, gastrointestinal bleedings or psychiatric disorders and can be considered as relatively safe.

Oppert et al. investigated the effect of low dose hydrocortisone on the reversal of septic shock in a randomized, double-blind, placebo-controlled trial including 41 patients. Hydrocortisone was administered initially as a $50 \mathrm{mg}$ bolus followed by a continuous infusion of $0.18 \mathrm{mg} / \mathrm{kg}$. After cessation of vasopressors, hydrocortisone was reduced to $0.06 \mathrm{mg} / \mathrm{kg}$ during $24 \mathrm{~h}$ then further tapered by $0.02 \mathrm{mg} / \mathrm{kg}$ every day. After randomization, the patients underwent a SST and were divided into responders and nonresponders to the synthetic ACTH. A significant reduction in the time to vasopressor withdrawal was noted. Indeed, the mean vasopressor administration time was $53 \mathrm{~h}$ for the hydrocortisone group, while it was $120 \mathrm{~h}$ for the placebo group. Once again, the nonresponders to the SST had a larger benefit of the replacement therapy. Mortality however was not affected by the hydrocortisone treatment nor was the complication rate. Furthermore, Oppert analyzed different plasma cytokine levels during the treatment period. The pro-inflammatory cytokine interleukin-6 (IL-6), the anti-inflammatory Interleukine-10 (IL$10)$, the ex vivo LPS-stimulated IL-6 production as well as the ex vivo LPS-stimulated IL-1 production were initially highly elevated but declined under the sepsis therapy. The decline in the interleukine levels were significantly faster in the hydrocortisone group than in the placebo group [33]. Other recent studies testing hydrocortisone in septic shock also showed a benefit in terms of duration of vasopressor therapy and mortality [33-37] (Table 2).

\section{Hydrocortisone and methylprednisolone in ARDS}

More recently, Annane et al. performed a post hoc analysis of the efficacy of low dose hydrocortisone in septic shock patients with or without early acute 
Table 2 Major randomized, double-blind, placebo-controlled trials assessing the effect of glucocorticoids in septic shock, ARDS, and severe pneumonia

\begin{tabular}{|c|c|c|c|}
\hline Trial & Method & Treatment & Outcome \\
\hline Bollaert, 1998 (France) & $\begin{array}{l}41 \text { adults } \\
\text { Septic shock } \\
2 \text { centers }\end{array}$ & $\begin{array}{l}\text { Hydrocortisone } 100 \mathrm{mg} \mathrm{IV} \\
\text { bolus every } 8 \mathrm{~h} \text { for } 5 \mathrm{~d} \\
\text { then tapered over } 6 \mathrm{~d}\end{array}$ & $\begin{array}{l}\text { Shock duration reduction: } 4 \mathrm{~d}(\mathrm{HC}) \text { vs } 13 \mathrm{~d}(\mathrm{P}) \\
\text { Shock patients at } \mathrm{d} 5:-47 \%(\mathrm{HC}) \\
\text { D28 mortality: }-31 \%(\mathrm{HC})\end{array}$ \\
\hline $\begin{array}{l}\text { Meduri, } 1998 \\
\text { (US) }\end{array}$ & $\begin{array}{l}24 \text { adults } \\
\text { Late ARDS } \\
1 \text { center }\end{array}$ & $\begin{array}{l}\text { Methylprednisolone } \\
2 \mathrm{mg} / \mathrm{kg} / \mathrm{d} \text { for } 14 \mathrm{~d} \\
\text { then tapered over } 24 \mathrm{~d}\end{array}$ & $\begin{array}{l}\text { Successful extubation at d10: } 7 \text { (MP) vs } 0 \text { (P) } \\
\text { ICU mortality: } 0 \%(M P) \text { vs } 63 \%(P) \\
\text { Hospital mortality: } 13 \%(M P) \text { vs } 63 \%(P)\end{array}$ \\
\hline $\begin{array}{l}\text { Briegel, } 1999 \\
\text { (Germany) }\end{array}$ & $\begin{array}{l}40 \text { adults } \\
\text { Septic shock } \\
1 \text { center }\end{array}$ & $\begin{array}{l}\text { Hydrocortisone } 100 \mathrm{mg} 30 \mathrm{~min} \\
\text { IV infusion }+0.18 \mathrm{mg} / \mathrm{kg} / \mathrm{h} \\
\text { continuous infusion until shock } \\
\text { reversal then tapered off }\end{array}$ & $\begin{array}{l}\text { Shock duration reduction: } 2 d(H C) \text { vs } 7 d(P) \\
\text { Reduction of MODS } \\
\text { No } d 28 \text { mortality reduction }\end{array}$ \\
\hline $\begin{array}{l}\text { Chawla, } 1999 \\
\text { (USA) }\end{array}$ & $\begin{array}{l}44 \text { adults } \\
\text { Septic shock } \\
1 \text { center }\end{array}$ & $\begin{array}{l}\text { Hydrocortisone } 100 \mathrm{mg} \mathrm{IV} \\
\text { bolus every } 8 \mathrm{~h} \text { for } 5 \mathrm{~d} \\
\text { then tapered over } 4 \mathrm{~d}\end{array}$ & $\begin{array}{l}\text { Shock duration reduction: } 3 \mathrm{~d}(\mathrm{HC}) \text { vs } 5 \mathrm{~d}(\mathrm{P}) \\
\text { Shock patients at } \mathrm{d} 3 \mathrm{-}-37 \%(\mathrm{HC}) \\
\text { D28 mortality: }-30 \%(\mathrm{HC})\end{array}$ \\
\hline $\begin{array}{l}\text { Yildiz, } 2002 \\
\text { (Turkey) }\end{array}$ & $\begin{array}{l}40 \text { adults } \\
\text { Sepsis (14), } \\
\text { Severe sepsis (17), } \\
\text { Septic shock (9) } \\
1 \text { center }\end{array}$ & $\begin{array}{l}\text { Prednisolone } 5 \mathrm{mg} \text { IV at } \\
6: 00 \text { and } 2.5 \mathrm{mg} \mathrm{IV} \text { at } \\
18: 00 \mathrm{pm} \text { for } 10 \mathrm{~d} \text { or placebo }\end{array}$ & D28 mortality: $-20 \%$ (Prednisolone) \\
\hline $\begin{array}{l}\text { Annane, } 2002 \\
\text { (France) }\end{array}$ & $\begin{array}{l}300 \text { adults } \\
\text { Septic shock } \\
19 \text { centers }\end{array}$ & $\begin{array}{l}\text { Hydrocortisone } 50 \mathrm{mg} \text { IV } \\
\text { bolus every } 6 \mathrm{~h}+\text { Fludrocortisone } \\
50 \mu \mathrm{g} / \mathrm{d} \text { orally for } 7 \mathrm{~d}\end{array}$ & $\begin{array}{l}\text { Shock duration reduction: } 7 \mathrm{~d}(\mathrm{HC}) \text { vs } 10 \mathrm{~d}(\mathrm{P}) \\
\text { Shock patients at } \mathrm{d} \text { : }-20 \%(\mathrm{HC}) \\
\text { D28 mortality: }-10 \%(\mathrm{HC})\end{array}$ \\
\hline $\begin{array}{l}\text { Keh, } 2003 \\
\text { (Germany) }\end{array}$ & $\begin{array}{l}40 \text { adults } \\
\text { Septic shock } \\
1 \text { center }\end{array}$ & $\begin{array}{l}\text { Hydrocortisone } 100 \mathrm{mg} 30 \mathrm{~min} \\
\text { IV infusion }+0.18 \mathrm{mg} / \mathrm{kg} / \mathrm{h} \\
\text { continuous infusion for } 3 \mathrm{~d}\end{array}$ & Shock patients at d3: $-40 \%$ (HC) \\
\hline $\begin{array}{l}\text { Confalonieri, } 2004 \\
\text { (Italy) }\end{array}$ & $\begin{array}{l}46 \text { adults } \\
\text { Severe community } \\
\text { acquired pneumonia } \\
6 \text { centers }\end{array}$ & $\begin{array}{l}\text { Hydrocortisone } 200 \mathrm{mg} \\
\text { IV bolus then } 10 \mathrm{mg} / \mathrm{h} \text { for } 7 \mathrm{~d}\end{array}$ & $\begin{array}{l}\text { Delayed septic shock: } 0(\mathrm{HC}) \text { vs } 9(\mathrm{P}) \\
\text { ARDS reduction at d7: }-48 \%(\mathrm{HC}) \\
\text { Hospital mortality: }-30 \%(\mathrm{HC}) \\
\text { D60 mortality: }-38 \%(\mathrm{HC})\end{array}$ \\
\hline $\begin{array}{l}\text { Oppert, } 2005 \\
\text { (Germany) }\end{array}$ & $\begin{array}{l}41 \text { adults } \\
\text { Septic shock } \\
1 \text { center }\end{array}$ & $\begin{array}{l}\text { Hydrocortisone } 100 \mathrm{mg} 30 \mathrm{~min} \\
\text { IV infusion }+0.18 \mathrm{mg} / \mathrm{kg} / \mathrm{h} \\
\text { continuous infusion until shock } \\
\text { reversal then tapered off }\end{array}$ & $\begin{array}{l}\text { Shock duration reduction: } 53 \mathrm{~h}(\mathrm{HC}) \text { vs } 120 \mathrm{~h}(\mathrm{P}) \\
\text { No } \mathrm{d} 28 \text { mortality reduction }\end{array}$ \\
\hline $\begin{array}{l}\text { Annane, } 2006 \\
\text { (France) }\end{array}$ & $\begin{array}{l}\text { Post hoc analysis } \\
300 \text { adults } \\
\text { Septic shock with ARDS } \\
\text { and nonresponders } \\
\text { to SST } 19 \text { centers }\end{array}$ & $\begin{array}{l}\text { Hydrocortisone } 50 \mathrm{mg} \text { IV } \\
\text { bolus every } 6 \mathrm{~h}+\text { Fludrocortisone } \\
50 \mu \mathrm{g} / \mathrm{d} \text { orally for } 7 \mathrm{~d}\end{array}$ & $\begin{array}{l}\text { Median time to death: } 8 \mathrm{~d}(\mathrm{P}) \text { vs } 17.5 \mathrm{~d}(\mathrm{HC}) \\
\text { D28 mortality: }-22 \%(\mathrm{HC}) \\
\text { No differences in septic shock without ARDS between HC } \\
\text { and } \mathrm{P} \text { group } \\
\text { No differences in responders between } \mathrm{HC} \text { and } \mathrm{P} \text { group }\end{array}$ \\
\hline
\end{tabular}

HC Hydrocortisone group, MP Methylprednisolone Group, P Placebo group, SST Short Synacthen Stimulation Test

respiratory distress syndrome (ARDS) using the data from their trial cited above [32]. The patients were separated into four groups according to their disease (septic shock patients with or without ARDS) and their SST results (responders or nonresponders). In the septic shock group with ARDS, the outcome in the nonresponder group was dependant on the treatment assigned. Indeed, the mean time to death was 8 days in the placebo group and 17 days in the hydrocortisone group. Days alive and off the ventilator were 2.6 \pm 6.6 among nonresponders treated by placebo versus $5.7 \pm 8.6$ for the treatment group. The increase in $\mathrm{P}_{\mathrm{a}} \mathrm{O}_{2} / \mathrm{F}_{\mathrm{i}} \mathrm{O}_{2}$ was higher in the treated nonresponder group and the mortality was significantly reduced in the treatment group. $75 \%$ of the placebo patients versus $53 \%$ of the treated patients died within 28 days.

Among responders to the SST no significant difference between treated groups and placebo groups was observed. In the septic shock group without ARDS the treatment with hydrocortisone did not show any benefit. Once again, no adverse events due to hydrocortisone were noted.

This post hoc analysis shows a clear benefit of hydrocortisone treatment in septic shock patients with ARDS who are nonresponders to the SST. It is important to note that the inefficiency of the hydrocortisone treatment in septic shock without ARDS should not lead to the conclusion that the benefit is due to a better treatment of ARDS. Indeed, the ret- 
rospective character of this work and the small study population does not allow such conclusion [38].

Interestingly, those findings keep in touch with the studies using methylprednisolone in late ARDS [3941]. In a randomized, placebo-controlled trial, Meduri et al. treated 24 patients with unresolving ARDS either with methylprednisolone or placebo. Steroids were begun if the Lung Injury Score (LIS) failed to improve by 1 point at day seven of respiratory failure. An initial intravenous loading dose of $2 \mathrm{mg} / \mathrm{kg}$ of methylprednisolone was given followed by a bolus of $0.5 \mathrm{mg} / \mathrm{kg}$ every 6 hours from day 1 to day 14. After day 14 methylprednisolone was tapered using a total dose of $1 \mathrm{mg} / \mathrm{kg} / \mathrm{d}$ from day 15 to day $21,0.5 \mathrm{mg} / \mathrm{kg} / \mathrm{d}$ from day 22 to day $28,0.25 \mathrm{mg} / \mathrm{kg} / \mathrm{d}$ on days 29 and 30 and $0.125 \mathrm{mg} / \mathrm{kg} / \mathrm{d}$ on days 31 and 32 . On day 10 of treatment, the methylprednisolone group had an improved $\mathrm{P}_{\mathrm{a}} \mathrm{O}_{2} / \mathrm{F}_{\mathrm{i}} \mathrm{O}_{2}$ ratio (262 vs 148 ), a better Lung Injury Score (1.7 vs 3.0) as well as more successful extubations ( 7 vs 0 ). Mean duration of mechanical ventilation was 11.5 days in the treatment group vs 23 days in the placebo group. The outcome was improved with methylprednisolone. In the treatment group, $100 \%$ of patient survived the ICU admission and $87 \%$ of the hospital admission, vs $37 \%$ and $37 \%$, respectively, of patients in the placebo group. A decrease in the plasma TNF- $\alpha$, IL1- $\beta$, and IL- 6 concentrations was observed in both groups, but the decrease was significantly higher and more sustained in the methylprednisolone group, hence providing supportive data for the presence of an endogenous glucocorticoid deficiency and a peripheral glucocorticoid resistance in unresolving ARDS [41]. Importantly, there was no significant difference in complications between the two groups [39].

\section{Hydrocortisone in pneumonia}

As in sepsis, the severity of community-acquired pneumonia is also related to the plasma inflammatory cytokine levels. Indeed, Il- $1 \beta$ seems to be a marker of the severity of infection, Il- 6 a marker of the severity of illness while TNF- $\alpha$ reflects the severity of pneumonia [42-44]. During severe community-acquired pneumonia, the leading cause of sepsis and septic shock, higher serum cytokine levels as well as a prolonged inflammatory response were correlated with a higher mortality $[45,46]$.

Confalioneri et al. hypothesized that low dose hydrocortisone administered in the early course of this disease may have the same positive effect on the outcome of severe community acquired pneumonia than during septic shock. In a multicenter, randomized, double-blind, placebo-controlled preliminary study,
46 patients admitted to the ICU because of severe community acquired pneumonia underwent corticosteroid replacement therapy [47]. Patients with clinical and radiographic evidence of pneumonia and either two minor or one major American Thoracic Society criterion for sever pneumonia were enrolled [48] (Table 3). Exclusion criteria were nosocomial pneumonia, acute burn injury, a preexisting medical condition with a life expectation of less than 3 months, as well as a condition requiring more than $0.5 \mathrm{mg} / \mathrm{kg} / \mathrm{d}$ of prednisolone (acute asthma, chronic obstructive pulmonary disease). Hydrocortisone was administered as a $200 \mathrm{mg}$ intravenous bolus followed by a continuous infusion of $10 \mathrm{mg} / \mathrm{h}$ during 7 days in parallel to the standard therapy. A diagnosis of adrenal insufficiency was not established. Primary endpoints were the improvement in $\mathrm{P}_{\mathrm{a}} \mathrm{O}_{2} / \mathrm{F}_{\mathrm{i}} \mathrm{O}_{2}$, development of the multiple organ dysfunction syndrome (MODS) and delayed septic shock. Secondary endpoints were time duration of mechanical ventilation, length of ICU and hospital stay, as well as the hospital and 60 day survival. The trial was stopped after the inclusion of 46 patients because a significant improvement in $\mathrm{P}_{\mathrm{a}} \mathrm{O}_{2} / \mathrm{F}_{\mathrm{i}} \mathrm{O}_{2}$ and hospital mortality was achieved in the treatment group.

Indeed, at baseline, the mean $\mathrm{P}_{\mathrm{a}} \mathrm{O}_{2} / \mathrm{F}_{\mathrm{i}} \mathrm{O}_{2}$ was lower in the hydrocortisone group (141 in the hydrocortisone group vs 178 in the placebo group). At day 8 , $\mathrm{P}_{\mathrm{a}} \mathrm{O}_{2} / \mathrm{F}_{\mathrm{i}} \mathrm{O}_{2}>300$ was obtained in $87 \%$ patients receiving hydrocortisone, while only $39 \%$ patients in the placebo group had a similar $\mathrm{P}_{\mathrm{a}} \mathrm{O}_{2} / \mathrm{F}_{\mathrm{i}} \mathrm{O}_{2}$. The development of MODS was also prevented through the hydrocortisone treatment. Only $35 \%$ patients in the hydrocortisone group developed MODS vs $70 \%$ in the placebo group. Hydrocortisone also appeared to be protective against development of delayed septic shock as $9(43 \%)$ patients in the placebo group needed vasopressors, while no such event was noted in the hydrocortisone group. The Duration of me-

Table 3 American Thoracic Society Criteria for severe pneumonia Major Criteria Minor criteria

1. Requirement of mechanical ventilation 1 . Respiratory rate $>30 \mathrm{bpm}$

2. Increase in the size of opacities on 2. $P_{a} O_{2} / F_{i} O_{2}<250$ chest radiograph of $50 \%$ or more in $48 \mathrm{~h}$

3. Requirement of vasopressors $>4$ hours

3. Bilateral or multilobar involvement on chest radiograph

4. Serum creatinine of $2 \mathrm{mg} / \mathrm{dl}$ or more 4 . Systolic blood pressure $\leq 90 \mathrm{mmHg}$

5. Diastolic blood pressure $\leq 60 \mathrm{mmHg}$

Severe pneumonia is defined clinical and radiographic evidence of pneumonia and 1 major criterion or 2 minor criteria 
chanical ventilation was reduced as the mean ventilation time was 10 days in the placebo group and 4 days in the treatment group. Furthermore, the ICU mortality ( $30 \%$ vs $0 \%)$ as well as the hospital $(30 \%$ vs. $0 \%)$ and 60 -day mortality $(38 \%$ vs $0 \%)$ were significantly reduced in the hydrocortisone group. There was no difference in complications attributable to hydrocortisone in either group [47].

This study provides positive data about the use of low dose hydrocortisone in severe community-acquired pneumonia admitted to the ICU. However, these results should be considered carefully. Due to the small patient sample, the randomization failed to provide two homogeneous groups. Baseline $\mathrm{P}_{\mathrm{a}} \mathrm{O}_{2} /$ $\mathrm{F}_{\mathrm{i}} \mathrm{O}_{2}$ was lower, mean CRP higher and the Chest Radiograph Score higher in the hydrocortisone group. Despite the current knowledge of the benefit of hydrocortisone in adrenal insufficiency, no screening for this condition was obtained. Hence there could be an imbalance in the two study groups with more adrenal insufficiency in the hydrocortisone treatment group which may explain their better results. Above all, the study was stopped early because of the perceived benefit. Considering the small sample group, the results have to be carefully evaluated. Although the mortality was significantly higher in the placebo group, very few incidents like one or two deaths in the treatment group, could have eliminated this difference. In conclusion, this preliminary study suggests a benefit of low dose hydrocortisone in severe community-acquired pneumonia but a larger trial with mortality as primary endpoint is necessary in order to confirm those results without major biases.

\section{Glucocorticoid safety}

Finally, it remains important to notice that low dose glucocorticoid treatment does not increase the risk of either gastroduadenal bleeding, superinfections or hyperglycemia as a large meta-analysis of 23 randomized and quasi-randomized trials proves [37].

\section{Conclusion}

Hydrocortisone should be used in sepsis and septic shock as several randomized, double-blind trials have shown a decrease of shock duration as well as an improved outcome. More recent trials have suggested a positive effect of this so-called replacement therapy in pneumonia and ARDS.

The mechanism for the hydrocortisone-induced benefit remains uncertain. In septic shock, it is assumed that an improved vasopressor responsiveness through the hydrocortisone treatment leads to a better outcome [49-51]. Recent data suggests that there is also a more proximal mechanism including the immune system. Multiple conditions such as severe pneumonia, sepsis or septic shock induce an exaggerated systemic inflammation with high Il-1, Il-6 and TNF- $\alpha$ levels. An impaired endogenous glucocorticoid production as found in adrenal insufficiency is unable to counterbalance the inflammatory response and may enhance severe tissue damage $[33,36,52]$.

Hence adrenal insufficiency screening should be performed in every ICU patient with severe disease. More recent data show that adrenal insufficiency is not limited to pneumonia, ARDS, sepsis or septic shock. A high incidence of pituitary failure was also found in acute liver failure and post-liver transplantation [53]. Low dose hydrocortisone replacement may improve the outcome in those patients as well.

\section{References}

1. Addison $\mathrm{T}$ (1855) On the constitutional and local effects of disease of the supra-renal capsules. Samuel Highlay, London

2. Bone RC, Fisher CJ Jr, Clemmer TP, Slotman GJ, Metz CA, Balk RA (1987) A controlled clinical trial of high-dose methylprednisolone in the treatment of severe sepsis and septic shock. N Engl J Med 317:653-658
3. Sprung CL, Caralis PV, Marcial EH, Pierce M, Gelbard MA, Long WM, Duncan RC, Tendler MD, Karpf M (1984) The effects of high-dose corticosteroids in patients with septic shock. A prospective, controlled study. N Engl J Med 311:1137-1143

4. Cronin L, Cook DJ, Carlet J, Heyland DK, King D, Lansang MA, Fisher C J Jr (1995) Corticosteroid treatment for sepsis: a critical appraisal and metaanalysis of the literature. Crit Care Med 23:1430-1439
5. Annane D (2005) Glucocorticoids in the treatment of severe sepsis and septic shock. Curr Opin Crit Care 11(11):449-453

6. Franchimont D, Kino T, Galon J, Meduri GU, Chrousos G (2002) Glucocorticoids and inflammation revisited: the state of the art. NIH clinical staff conference. Neuroimmunomodulation 10:247-260

7. Marik PE, Zaloga GP (2003) Adrenal insufficiency during septic shock. Crit Care Med 31:141-145 
8. Marik PE, Zaloga GP (2002) Adrenal insufficiency in the critically ill: a new look at an old problem. Chest 122:1784-1796

9. Zaloga GP (2001) Sepsis-induced adrenal deficiency syndrome. Crit Care Med 29:688-690

10. Grinspoon SK, Bilezikian JP (1992) HIV disease and the endocrine system. N Engl J Med 327:1360-1365

11. Sonino N (1986) The endocrine effects of ketoconazole. J Endocrinol Invest 9:341-347

12. Smith GH (1994) Treatment of infections in the patient with acquired immunodeficiency syndrome. Arch Intern Med 154:949-973

13. Marik PE, Zaloga GP (2002) Adrenal insufficiency in the critically ill: a new look at an old problem. Chest 122:1784-1796

14. den Brinker M, Joosten KF, Liem O, de Jong FH, Hop WC, Hazelzet JA, van Dijk $M$, Hokken-Koelega AC (2005) Adrenal insufficiency in meningococcal sepsis: bioavailable cortisol levels and impact of interleukin-6 levels and intubation with etomidate on adrenal function and mortality. J Clin Endocrinol Metab 90:5110-5117

15. Jackson WL Jr (2005) Should we use etomidate as an induction agent for endotracheal intubation in patients with septic shock?: a critical appraisal. Chest 127:1031-1038

16. Jaattela $M$, Ilvesmaki V, Voutilainen R, Stenman UH, Saksela E (1991) Tumor necrosis factor as a potent inhibitor of adrenocorticotropin-induced cortisol production and steroidogenic P450 enzyme gene expression in cultured human fetal adrenal cells. Endocrinology 128:623-629

17. Schlaghecke R, Kornely E, Santen RT, Ridderskamp P (1992) The effect of long-term glucocorticoid therapy on pituitary-adrenal responses to exogenous corticotropin-releasing hormone. N Engl J Med 326:226-230

18. Krasner AS (1999) Glucocorticoidinduced adrenal insufficiency. JAMA 282:671-676

19. Henzen C, Suter A, Lerch E, Urbinelli R, Schorno XH, Briner VA (2000) Suppression and recovery of adrenal response after short-term, high-dose glucocorticoid treatment. Lancet 355 : 542-545

20. Kannisto S, Korppi M, Remes K, Voutilainen R (2000) Adrenal suppression, evaluated by a low dose adrenocorticotropin test, and growth in asthmatic children treated with inhaled steroids. J Clin Endocrinol Metab 85:652-657
21. Broide J, Soferman R, Kivity S, Golander A, Dickstein G, Spirer Z, Weisman Y (1995) Low-dose adrenocorticotropin test reveals impaired adrenal function in patients taking inhaled corticosteroids. J Clin Endocrinol Metab 80:1243-1246

22. Beishuizen A, Thijs LG, Vermes I (2001) Patterns of corticosteroidbinding globulin and the free cortisol index during septic shock and multitrauma. Intensive Care Med 27:15841591

23. Pugeat $\mathrm{M}$, Bonneton $\mathrm{A}$, Perrot $\mathrm{D}$, Rocle-Nicolas B, Lejeune $\mathrm{H}$, Grenot $\mathrm{C}$, Dechaud H, Brebant C, Motin J, Cuilleron CY (1989) Decreased immunoreactivity and binding activity of corticosteroid-binding globulin in serum in septic shock. Clin Chem 35:16751679

24. Naito Y, Fukata J, Tamai S, Seo N, Nakai Y, Mori K, Imura H (1991) Biphasic changes in hypothalamo-pituitary-adrenal function during the early recovery period after major abdominal surgery. J Clin Endocrinol Metab 73:111-117

25. Barquist E, Kirton O (1997) Adrenal insufficiency in the surgical intensive care unit patient. J Trauma 42:27-31

26. Kidess AI, Caplan RH, Reynertson RH, Wickus GG, Goodnough DE (1993) Transient corticotropin deficiency in critical illness. Mayo Clin Proc 68:435-441

27. Cooper MS, Stewart PM (2003) Corticosteroid insufficiency in acutely ill patients. N Engl J Med 348:727-734

28. Prigent $\mathrm{H}$, Maxime $\mathrm{V}$, Annane $\mathrm{D}$ (2004) Clinical review: corticotherapy in sepsis. Crit Care 8:122-129

29. Schroeder S, Wichers M, Klingmuller D, Hofer M, Lehmann LE, von Spiegel T, Hering R, Putensen C, Hoeft A, Stuber F (2001) The hypothalamic-pituitary-adrenal axis of patients with severe sepsis: altered response to corticotropin-releasing hormone. Crit Care Med 29:310-316

30. Maghnie M, Uga E, Temporini F, Di Iorgi N, Secco A, Tinelli C, Papalia A, Casini MR, Loche S (2005) Evaluation of adrenal function in patients with growth hormone deficiency and hypothalamic-pituitary disorders: comparison between insulin-induced hypoglycemia, low-dose ACTH, standard ACTH and $\mathrm{CRH}$ stimulation tests. Eur J Endocrinol 152:735-741

31. Annane D, Sebille V, Troche G, Raphael JC, Gajdos P, Bellissant E (2000) A 3-level prognostic classification in septic shock based on cortisol levels and cortisol response to corticotropin. JAMA 283:1038-1045
32. Annane D, Sebille V, Charpentier C, Bollaert PE, Francois B, Korach JM, Capellier G, Cohen Y, Azoulay E, Troche G, Chaumet-Riffaut P, Bellissant E (2002) Effect of treatment with low doses of hydrocortisone and fludrocortisone on mortality in patients with septic shock. JAMA 288:862-871

33. Oppert M, Schindler R, Husung C, Offermann K, Graf KJ, Boenisch O, Barckow D, Frei U, Eckardt KU (2005) Low-dose hydrocortisone improves shock reversal and reduces cytokine levels in early hyperdynamic septic shock. Crit Care Med 33:24572464

34. Bollaert PE, Charpentier C, Levy B, Debouverie M, Audibert G, Larcan A (1998) Reversal of late septic shock with supraphysiologic doses of hydrocortisone. Crit Care Med 26:645650

35. Briegel J, Forst H, Haller M, Schelling G, Kilger E, Kuprat G, Hemmer B, Hummel T, Lenhart A, Heyduck M, Stoll C, Peter K (1999) Stress doses of hydrocortisone reverse hyperdynamic septic shock: a prospective, randomized, double-blind, singlecenter study. Crit Care Med 27:723732

36. Keh D, Boehnke T, Weber-Cartens S, Schulz C, Ahlers O, Bercker S, Volk HD, Doecke WD, Falke KJ, Gerlach H (2003) Immunologic and hemodynamic effects of "low-dose" hydrocortisone in septic shock: a doubleblind, randomized, placebo-controlled, crossover study. Am J Respir Crit Care Med 167:512-520

37. Annane D, Bellissant E, Bollaert PE, Briegel J, Keh D, Kupfer Y (2004) Corticosteroids for severe sepsis and septic shock: a systematic review and meta-analysis. BMJ 329:480

38. Annane D, Sebille V, Bellissant E (2006) Effect of low doses of corticosteroids in septic shock patients with or without early acute respiratory distress syndrome. Crit Care Med 34:22-30

39. Meduri GU, Headley AS, Golden E, Carson SJ, Umberger RA, Kelso T, Tolley EA (1998) Effect of prolonged methylprednisolone therapy in unresolving acute respiratory distress syndrome: a randomized controlled trial. JAMA 280:159-165

40. Meduri GU, Chrousos GP (2006) Effectiveness of prolonged glucocorticoid treatment in acute respiratory distress syndrome: the right drug, the right way? Crit Care Med 34:236238 
41. Meduri GU, Tolley EA, Chrousos GP, Stentz F (2002) Prolonged methylprednisolone treatment suppresses systemic inflammation in patients with unresolving acute respiratory distress syndrome: evidence for inadequate endogenous glucocorticoid secretion and inflammation-induced immune cell resistance to glucocorticoids. Am J Respir Crit Care Med 165:983-991

42. Puren AJ, Feldman C, Savage N, Becker PJ, Smith C (1995) Patterns of cytokine expression in communityacquired pneumonia. Chest 107:13421349

43. Schutte H, Lohmeyer J, Rosseau S, Ziegler S, Siebert C, Kielisch H, Pralle H, Grimminger F, Morr H, Seeger W (1996) Bronchoalveolar and systemic cytokine profiles in patients with ARDS, severe pneumonia and cardiogenic pulmonary oedema. Eur Respir J 9:1858-1867

44. Fernandez-Serrano S, Dorca J, Coromines M, Carratala J, Gudiol F, Manresa F (2003) Molecular inflammatory responses measured in blood of patients with severe community-acquired pneumonia. Clin Diagn Lab Immunol 10(10):813-820
45. Park DR, Skerrett SJ (1996) IL-10 enhances the growth of Legionella pneumophila in human mononuclear phagocytes and reverses the protective effect of IFN-gamma: differential responses of blood monocytes and alveolar macrophages. J Immunol 157:2528-2538

46. van Dissel JT, van Langevelde P, Westendorp RG, Kwappenberg K, Frolich M (1998) Anti-inflammatory cytokine profile and mortality in febrile patients. Lancet 351:950-953

47. Confalonieri M, Urbino R, Potena A, Piattella M, Parigi P, Puccio G, Della Porta R, Giorgio C, Blasi F, Umberger R, Meduri GU (2005) Hydrocortisone infusion for severe community-acquired pneumonia: a preliminary randomized study. Am J Respir Crit Care Med 171:242-248

48. Niederman MS, Bass J B Jr, Campbell GD, Fein AM, Grossman RF, Mandell LA, Marrie TJ, Sarosi GA, Torres A, Yu VL (1993) Guidelines for the initial management of adults with community-acquired pneumonia: diagnosis, assessment of severity, and initial antimicrobial therapy. American Thoracic Society. Medical Section of the American Lung Association. Am Rev Respir Dis 148:1418-1426
49. Oppert $\mathrm{M}$, Reinicke A, Graf KJ, Barckow D, Frei U, Eckardt KU (2000) Plasma cortisol levels before and during "low-dose" hydrocortisone therapy and their relationship to hemodynamic improvement in patients with septic shock. Intensive Care Med 26:1747-1755

50. Annane D, Bellissant E, Sebille V, Lesieur O, Mathieu B, Raphael JC, Gajdos P (1998) Impaired pressor sensitivity to noradrenaline in septic shock patients with and without impaired adrenal function reserve. $\mathrm{Br} \mathrm{J}$ Clin Pharmacol 46:589-597

51. Szabo C, Thiemermann C, Wu CC, Perretti M, Vane JR (1994) Attenuation of the induction of nitric oxide synthase by endogenous glucocorticoids accounts for endotoxin tolerance in vivo. Proc Natl Acad Sci USA 91:271-275

52. Briegel J, Jochum M, Gippner-Steppert C, Thiel M (2001) Immunomodulation in septic shock: hydrocortisone differentially regulates cytokine responses. J Am Soc Nephrol 12 (Suppl 17):S70-S74

53. Marik PE, Gayowski T, Starzl TE (2005) The hepatoadrenal syndrome: a common yet unrecognized clinical condition. Crit Care Med 33:12541259 